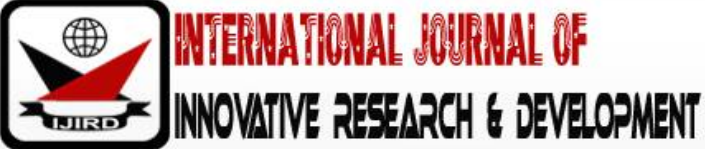

ISSN 2278 - 0211 (Online)

\section{Ascertaining the Constraints Faced in Accessing Loan by Small Scale Crops Farmers in Toro Local Government Area of Bauchi State, Nigeria}

\author{
Bassey Emmanuel Akpan \\ Principal Instructor, Montane Forest Research Station Jos, Plateau State, Nigeria \\ Ubana Eshimutu \\ Chief Instructor, Montane Forest Research Station Jos, Plateau State, Nigeria \\ Odeh Catherine \\ DMS Operator, Guinness Nigeria, Peterco, Busabuji Jos, Plateau State, Nigeria
}

\begin{abstract}
:
Lack of capital has been identified as one of the constraints faced by small scale farmers. The aim of the research was to examine the constraints face by small scale crops farmers in Toro L.G.A, of Bauchi State, Nigeria. Data for this study was obtained mainly from primary source of information by the used of well-structured questionnaire and oral interviews a total number of 119 crop farmers from six (6) communities in the study area were selected. Data was analyzed using five (5) point Likert scale of strongly agreed, agreed, neutral, strongly disagreed and disagreed. The result review that delayed in disbursement of agricultural credit is one of the major problems encountered with mean of (3.90), followed by too much bank requirement (3.84), while interest rate is the least problem with (3.72). This study was recommended that small scale crop farmers in the study area should form cooperative organization to help them get easy access to credit/ loan at the right time.
\end{abstract}

Keywords: Constraints, farmers, access, loan

\section{Introduction}

Small scale farmers have always played dominant role in agricultural productivity in Nigeria (Rahji and Fakayode, 2009), but their productivity and growth are hindered by limited access to credit facilities (Odoemenem and Obinne, 2010). Capital has for a long time been considered as a primary means of rekindling and enhancing the growth potential of the rural economy, especially farming activities (Eboreime, 2008).

One of the principal characteristics of informal credits as stated by Okojie et al (2010), is the highest interest rates imposed on loans relatives to those by the formal banking sector. But this applies more to the informal credit institution (money lenders), credit from co-operative societies generally attracts interest rates of less than 10 percent. According to Okojie et al; (2010), the lack of bank accounts, collateral, and information regarding the procedure for accessing credits from banks limit rural farmers access to credits from Banks. Formal credit market in rural areas are often constructed by inadequate property rights and high transaction cost. Credit is an important instrument for improving the welfare of the poor, directly through consumption smoothening.

\subsection{Problem Statement}

Lack of bank accounts, lack of collateral, and lack of information regarding the procedure for accessing credits from bank limits rural women's access to credit from formal institute (Okojie et al; (2010). Bolarinwa and Oyeyinka (2005) that inadequate credit provision and poor marketing systems have induced agriculture productivity drastically to the extent that food importation has been on the increase in recent year. Rahji and Fakayode (2009) blamed the limitation on imperfect and costly information problem encountered in the financial markets, credit rationing policy and banks perception of agriculture credit at a high risky venture. Lack of bank accounts, lack of collateral, and lack of information regarding the procedure for accessing credit from formal instate (Okojie et al; 2010). Philip et al; (2009) Stated that high interest rate and the short - term nature of loans with fixed payment periods do not suit annual cropping and thus constitute a hindrance to credit access. The objective is to identify problems encountered by sampled small-scale crops farmers in the study area. 


\section{Methodology}

\subsection{Study Area and Data Collection}

Toro Local Government was created in 1974 from former Bauchi State native authority. It is $98 \mathrm{~km}$ away from Bauchi, its headquarters is in the Toro town, it is the largest and longest local government in Bauchi State, Nigeria. The local government shares common boundaries with Plateau State in the South East, Kaduna in the West and Kano in the South. The study area has a population of 350,404 people (2006 Census) and an area of about 7,389 square kilometers which makes it one of the largest local government in the State. Toro local government is a topographically hilly with attitude 1.100 meters above sea level, it is located on longitude $10^{\circ}$ and $10^{\circ} \mathrm{N}$ and latitude $14^{\circ}$ and $14^{\mathrm{K}} \mathrm{E}$. It falls in the Sudan Savannah zone in the Northern part of the country with average rainfall ranges from $8307 \mathrm{~mm}$ to $1100 \mathrm{~mm}$ annually start from April to October. Toro Local Government area generally has a fair weather with temperatures ranges between $35^{\circ} \mathrm{C}$ for lowland and $31^{\circ} \mathrm{C}$ for highland. The Zeem Language is spoken in Toro apart from their many languages spoken within and outside Toro which are, Fulani, Ribina, Hausa, Jarawa, Zakasawa abd Zari. There are three major districts that makes of the Local Government, they are: Toro district with the headquarters at Nabardo. The people of Toro Local Government are predominantly farmers and the crops grown in the Local Government include sweet potato, maize, rice, sorghum, cowpea and soya beans.

The population of study covers the small-scale crop farmers in Toro Local Government area of Bauchi State. The first stage involves a random selection of three wards which include Julai ward, Wonu South ward, and Palama ward. The second stage involve purposive selection of two communities each from the three wards which includes, Tudun Wada, Kotono, Diriko, Jamaire, Stakuwa and Tilbale to arrive at six (6) communities. This was done chiefly on their involvement in farming activities using Taro-yamane formula was used to determine the sample size.

\section{$\underline{\mathrm{N}}$}

$\left.\overline{1+\mathrm{N}^{2}}\right)$

$\mathrm{N}=$ Population size

$\mathrm{S}=$ Sample size required

$\mathrm{E}=$ Level of significance.

This give us total correspondents of 120 questionnaires to prevent biases and ensured the degree of accuracy that will allow for making influence applicable to a wider population.

\subsection{Data Analysis}

Data was analyzed using 5point Likert scale.

\subsection{Problems Encountered in Accessing Agricultural Credit}

The results of respondent's perception on problems encountered in accessing agricultural credit are presented in Table 1. From the response sourced, it reveals that average of (3.84) perceived that too much bank requirement is seen as problems encountered in accessing agricultural credit, about (3.59) perceived that the problems can be due to lack of collateral security, (3.77) due to insufficient amount to be distributed, (3.90) believed that it may be delay in disbursement of Agricultural credit, (3.72) agrees that problems encountered in accessing agricultural credit is due to high interest rate, while about (3.73) believe that reduction in the actual amount applied are encountered problems in accessing agricultural credit. Base on the average result, it implies that the respondents strongly agrees with the problems encountered in accessing agricultural credit in the study area.

\begin{tabular}{|c|c|c|c|c|c|c|c|}
\hline Factors (n = 119) & SA (5) & A (4) & N (3) & SD (2) & D (1) & Total & Mean \\
\hline Too much Bank requirement & 39 & 37 & 33 & 5 & 5 & 457 & 3.84 \\
\hline Lack of collateral security & 27 & 34 & 44 & 10 & 4 & 427 & 3.59 \\
\hline Insufficient amount to be distributed & 37 & 34 & 36 & 8 & 4 & 449 & 3.77 \\
\hline Delay in disbursement of Agricultural credit & 45 & 32 & 31 & 7 & 4 & 464 & 3.90 \\
\hline High interest rate & 32 & 40 & 35 & 6 & 6 & 443 & 3.72 \\
\hline Reduction in the actual amount applied & 42 & 27 & 35 & 6 & 9 & 444 & 3.73 \\
\hline
\end{tabular}

Table 1: Linkert Scale Showing the Result of Respondent's Perception on Problems Encountered in Accessing Agricultural Credit

Note: $\mathrm{SA}=$ Strongly Agree, $\mathrm{A}=$ Agree, $\mathrm{N}=$ Neutral, $\mathrm{D}=$ Disagree, $\mathrm{SD}=$ Strongly Disagree

(Mean Score $>3.0=$ High Determinant Factor)

Source: Field Survey, 2018

Another important factor that has been empirically proven to influence agricultural production is accessibility to credit. (akinseinde, 2006) Evince that having access to credit facilities contributed positively to household.

This result is in line with the finding of (Akramov, 2009) that only few percent of farmer households have access to financial service. 


\section{Conclusion and Recommendation}

The role of agricultural credit in the development of agricultural sector cannot be overemphasized. Credit enhances farmers purchasing power to enabling them acquires modern technologies for their production. Agricultural credit enhances productivity and promotes standard of living by breaking various causes of low productivity by small scale farmers. The study revealed lack of collaterals as one of the problems faced by small scale farmers in accessing loans or credit. Access to credit seems to be limited among small holder's farmers due to constant constraints. This study has identified some of the constraints as:

- Delayed in disbursement of agricultural credit

- Too much bank requirement,

- High interest rate

- Reduction in actual among and

- Lack of collateral

\subsection{Recommendation}

- Enabling environment should be created to improve farmer's accessibility to credit facilities, this can be achieved through mass education about credit for rural dwellers and functional extension activities in all area of the state.

- Banks should be encouraged to open branches in most parts of the rural area to remove the stress of loan acquisition by farmers.

- Loan should be disbursed to farmer on timely basis with low interest rate to encourage farmers to collect loan and increase their productivity. Banks should be widely spread for easy means of credit to farmers at different locations.

\section{Reference}

i. Akinseinde (2006). Non - Farm Activity and production Efficiency of farm Household in Egbede Local Government Area of Oyo State, Nigeria. An Unpublished M.Sc. Project Department of Agricultural Economics, University of Ibadan 2006.

ii. Akramove.H. (2009). Decentralization/ Agricultural Service and Determinant of input use in Nigeria. Discussion paper 941 Washington, D.C. International food policy Research Institute 2009.

iii. Bolarinwa. K.K. and Oyeyinka R.A (2005). Communal Conflict impact on Agricultural Extension Agents Operation in Atisbo Local Government Area of Oyo State' Journal of Agric. Extension 8(1).

iv. Eboreime, MI (2008). Approaches to micro finance in developing countries. Lesson for Rural Poverty Reduction in Nigeria. In Igbozurike et al (eds.) Rural Poverty in Nigeria. Cape publishers int'l Ltd Abuja. Nigeria. Pp.343 - 354.

v. Odoemenem, I.U and Obinee, C.P.O.(2010). Accessing the factors influencing the utilization of improved cereal crop production technologies by small - scale farmers in Nigeria.

vi. Okojie, C, Monye - Emina, A. Eghafona, K. Osaghae, G; and Ehiakhamen.J. O (2010). Institutional environment and access to microfinance by self-employed woman in the Rural Area of Edo State. NSSP Brief No.14 Washington D.C International food policy research Institute.

vii. Olagunju, F.I and Adeyemo, R. (2008). Evaluation of the operational performance of the Nigeria Agricultural credit cooperative and rural development Bank (NACRDB) in south western Nigeria, IJAERD PRESS.

viii. Philips.D. Nkonya, E. Pender.J. and Oni. O.A (2009). Constraints to increasing Agricultural productivity in Nigeria. A review. Nigeria strategy support program (NSSP). Background paper No NSSP 006.

ix. Rahji, M.A.Y. and Fakayode, S.A (2009). A multinomial logit analysis of Agricultural credit Rationing by commercial Banks in Nigeria. International Research Journal of finance and Economic, 24:91. 